\title{
Empathic listening: welcoming strategy for nursing Professional in coping with with the coronavirus pandemic
}

\author{
Escuta empática: estratégia de acolhimento aos profissionais de enfermagem no enfrentamento da \\ pandemia por coronavírus \\ Escucha empática: estrategia de bienvenida para los profesionales de enfermería para hacer frente a la \\ pandemia de coronavirus
}

\section{Lucia Tobase \\ ORCID: 0000-0003-2289-4482 \\ Sandra Helena Cardoso" ORCID: 0000-0002-5017-0476 \\ Renata Tavares Franco Rodrigues " ORCID: 0000-0003-0488-8230 \\ Heloisa Helena Ciqueto Peres" ORCID: 0000-0002-8759-5670}

'Centro Universitário São Camilo. São Paulo, São Paulo, Brazil. "Universidade de São Paulo. São Paulo, São Paulo, Brazil.

How to cite this article: Tobase L, Cardoso SH, Rodrigues RTF, Peres HHC. Empathic listening: welcoming strategy for nursing Professional in coping with with the coronavirus pandemic Rev Bras Enferm. 2021;74(Suppl 1):e20200721. doi: http://dx.doi.org/10.1590/0034-7167-2020-0721

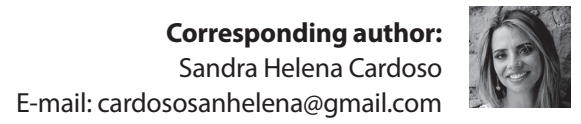

EDITOR IN CHIEF: Dulce Barbosa ASSOCIATE EDITOR: Hugo Fernandes

Submission: $06-28-2020$

Approval: $10-03-2020$

\begin{abstract}
Objective: to reflect on empathic listening use as a welcoming strategy for nursing professionals to cope with the challenges during the pandemic caused by the new coronavirus. Methods: this is a reflection study based on updated data surveys and theoretical-conceptual aspects of Non-Violent Communication and empathic listening. Results: in the performance during the COVID-19 pandemic, nursing professionals are exposed to violence of different natures related to occupational stress, work overload, anguishes and silenced suffering, with implications for the workers' health, who can be benefited and strengthened with empathetic listening. Final considerations: the health crisis has highlighted the weaknesses of the health system. Nursing acts as the largest contingent of the health workforce in coping with the pandemic. Empathetic listening is a powerful strategy in caring for and strengthening nursing professionals.

Descriptors: Coronavirus; Pandemic; Empathy; User Embracement; Nurse Practitioners.
\end{abstract}

\section{RESUMO}

Objetivo: refletir sobre a utilização da escuta empática como estratégia de acolhimento aos profissionais de enfermagem no enfrentamento dos desafios durante a pandemia pelo novo coronavírus. Métodos: estudo do tipo reflexão, realizado com base em levantamentos de dados atualizados e aspectos teórico-conceituais da Comunicação Não Violenta e escuta empática. Resultados: na atuação durante a pandemia de COVID-19, o profissional de enfermagem está exposto a violências de diferentes naturezas relacionadas ao estresse ocupacional, sobrecarga de trabalho, angústias e sofrimentos silenciados, com implicações na saúde do trabalhador, que pode ser beneficiado e fortalecido com a escuta empática. Considerações finais: a crise sanitária tem evidenciado as fragilidades do sistema de saúde. A enfermagem atua como o maior contingente da força de trabalho em saúde no enfrentamento da pandemia. A escuta empática é uma estratégia potente na atenção e fortalecimento dos profissionais de enfermagem.

Descritores: Infecção por Coronavírus; Pandemia; Empatia; Acolhimento; Profissionais de Enfermagem.

\section{RESUMEN}

Objetivo: reflexionar sobre el uso de la escucha empática como estrategia de acogida de los profesionales de enfermería para afrontar los retos durante la pandemia provocada por el nuevo coronavirus. Métodos: estudio de reflexión, basado en datos actualizados y aspectos teóricos y conceptuales de la Comunicación No Violenta y la escucha empática. Resultados: en el desempeño durante la pandemia COVID-19, el profesional de enfermería se encuentra expuesto a violencias de diversa índole relacionadas con el estrés ocupacional, sobrecarga laboral, angustias y sufrimientos silenciados, con implicaciones para la salud del trabajador, que pueden ser beneficiadas y fortalecidas. con escucha empática. Consideraciones finales: la crisis sanitaria ha puesto de manifiesto las debilidades del sistema sanitario. La enfermería actúa como el mayor contingente del personal sanitario para hacer frente a la pandemia. La escucha empática es una poderosa estrategia en el cuidado y fortalecimiento de los profesionales de enfermería.

Descriptores: Infecciones por Coronavirus; Pandemia; Empatía; Acogimiento; Enfermeras Practicantes. 


\section{INTRODUCTION}

At the end of January 2020, the World Health Organization (WHO) declared a Public Health Emergency of International Concern due to the global spread of the acute respiratory disease COVID-19, caused by the new coronavirus SARS-COV-2. In Brazil, in March 2020, the state of community transmission was declared nationwide, with a progressive increase in the number of new cases, an increase in hospitalizations and deaths, as observed in other countries ${ }^{(1)}$.

The spread of infectious disease, affecting different countries and continents, infecting large numbers of people, characterizes the pandemic condition, such as COVID-19(1). Prior to this scenario, nursing professionals had already faced issues such as a deficit of professionals to assist society, inadequate working conditions, the need for training and improvement in education and leadership, considered as challenges discussed by WHO and focuses of the Nursing Now campaign in international action for nursing valorization and empowerment ${ }^{(2)}$.

Before the current pandemic, the challenges have taken on new proportions. The expressive demand to care for a large number of people in a short period of time exposed weaknesses in the health system, causing an overload of health services and professionals, especially nursing. The surveys of the Federal Nursing Council (COFEN - Conselho Federal de Enfermagem) on data from the Nursing Observatory indicate, until September 2020, approximately 39,858 reported cases and 434 deaths of professionals ${ }^{(3)}$.

Despite these alarming data, the pandemic has given professionals greater visibility. Press, media, and social networks often pay tribute to workers working on the front lines in the fight against COVID-19. WHO and the authorities of several countries have highlighted the valorization of nursing professionals, hailed as heroes by different segments of society. However, taking on such a role can reinforce, in workers, the attitude of being strong, without admitting or expressing personal and professional vulnerabilities in the face of arduous challenges. They are mistaken attitudes, incompatible with the human being, and do not make them immune to tiredness, psychological distress, and illness.

Therefore, how to defend nursing and overcome challenges? How to conquer space in the health system to give professionals a voice before suffering and heavy burden sustained in this tense historical moment? In this perspective, new movements are necessary for public policy proposals, restructuring services and reorganizing work processes. This complex conjuncture leads to reflection on the implications of the pandemic on nursing workers facing COVID-19.

In the dimension of workers' health care, in welcoming and strengthening professionals, empathic listening has been used as a powerful strategy in the unfolding of Non-Violent Communication (NVC), proposed by Marshall Rosenberg. Starting from the premise that conflicts are triggered by incomprehension about the real reasons, in relationships with others or with oneself, which generate pain and discomfort, it is a natural tendency for instinctive reactions to translate into violent behaviors Empathetic communication seeks to bring awareness, with affection, respect, empathy and generosity, to transform these relationships. From self-perception and self-knowledge, it allows individuals to identify their own feelings and needs, understand their weaknesses and recognize their potential. This clarity gives a sense of relief when they see themselves more aware of the new condition, realizing their own limits and new possibilities for rearrangements in relationships. Exercising empathy in (self) reception decreases the degree of suffering, anxiety, and tension, contributing to the development of internal resources to cope with challenges ${ }^{(4)}$.

Therefore, this study aims to reflect on empathic listening use as a welcoming strategy for nursing professionals in facing the challenges during the pandemic caused by the new coronavirus.

\section{Occupational stress, work overload, anguish and silenced suffering as forms of violence and its implications reinforced during the pandemic}

Violence at work is a broad and multifactorial phenomenon, defined as aggressive interaction experienced in work circumstances, putting the professional's safety, well-being or health at risk. It can occur in a physical, psychological or moral way, covering relationships, organization and working conditions, in addition to negligence, omission in the face of some misfortune or naturalization of the death and illness of the worker ${ }^{(5)}$.

In this sense, structural aspects, inadequate working conditions, scarcity of resources, conflicts with managers and organizational elements with incongruous work processes are also factors that promote occupational violence, with serious repercussions on workers' health. Physiologically, repressed violence weakens the immune system and promotes illness ${ }^{(6)}$.

In the pandemic, the demand for more professional attention in comprehensive care in numerous cases of greater urgency and severity, patients in different age groups, many with unfavorable prognoses, generates anguish, frustration and emotional exhaustion in the struggle for life. In addition, long hours of work cause occupational stress, physical and mental tiredness, reduced performance, risks of depressive and anxious disorders, and increased absenteeism ${ }^{(6)}$, making the problem cyclical, especially in hospital institutions, when the dimensioning of personnel is not is readjusted.

The mental health of professionals is also seriously affected when faced with the significant increase in deaths due to complications from COVID-19. This reality requires attention due to the risk of professionals interpreting death as a personal failure ${ }^{(7)}$. Such a distorted perception can culminate in the attempt of selfextermination and of others. Facing death causes fear of losing members of the work team, family members and loved ones: who will be next to be infected? Will I transmit the disease to my family members? If I get infected, will I survive? If I die, who will take care of my children?

Lack of control over end of life, depending on the socio-cultural context, can be translated into anxieties and frustrations. Workers working with terminally ill patients report that the mourning caused by loss of patients is not allowed to be experienced, whether due to personal self-protection mechanisms, lack of preparation during training or absence of a welcoming work environment. Nurses are actors in the cycle of professional anguish, when professional training does not address the management of frustration due to death, and the reduced arsenal of resources in the elaboration of coping strategies makes them psychically vulnerable in practice ${ }^{(7)}$. 
Both the history of hospital institutions and scientific nursing have, in their genesis, aspects that compelled professionals to adopt rigid attitudes, without showing suffering before pain and anguish. From the $20^{\text {th }}$ century, with the advancement of science, patients stopped being treated at home to be assisted in hospitals. In this environment, when providing technical care, professionals were required to control emotions to protect the institutional routine. As part of such a socio-political-cultural archetype, nursing professionalization also carries, in its history and formation, the heritage of the Nightingale school, with military and religious principles, firm attitudes and limited expression of feelings at work, even before death ${ }^{(7)}$.

Nowadays, due to personal, cultural, and historical issues of the profession, nursing still has difficulty expressing its psychological distress. On the other hand, from the perspective of some institutions, aiming at the rationality of work and optimization of resources, they do not provide openness and support for workers to manifest their pains and anguishes, difficulties and concerns related to work ${ }^{(7)}$.

In a survey conducted in Rio Grande do Sul State, nurses reported hopelessness and impotence in the face of care protocols and limited space in the institution to express themselves: "Nurses had insights on improvements in care and in their relationship with work. However, at the time of suffering and concern, they were not heard"(7). Sometimes professionals are harassed by managers who do not listen or value new propositions.

The impossibility of expressing personal anguish and suffering in the exercise of the profession suffocates the nursing voice, preventing the re-signification of the practice. Thus, work can become a link of toxicity, compromising the ability to reflect on the care for oneself and the other. Dissatisfaction triggers hostility among professionals, patients and family members, compromising patient safety, quality of care and visibility of the institution ${ }^{(8)}$.

Importance and benefits of empathic listening and Nonviolent Communication during the pandemic as a welcoming and strengthening strategy for nursing professionals

The pandemic, added to social isolation/distance, causes countless impacts on people's lives and the adoption of new behaviors, on family and social coexistence, on remote education and work models, whose adaptation can be positive or generate suffering. Directly, nursing professionals were not affected by isolation, but the daily routine was modified, with greater family demand, which caused a decrease in rest and rest.

In this context, people's mental health has become a target of attention for researchers, professionals and volunteers due to increase in manifestations such as fear, insecurity due to uncertainties, sadness, irritation and anger, insomnia, fever, depression, anxiety, alcohol, and medication abuse psychotropic ${ }^{(9)}$. In the management of these manifestations, several measures are indicated, from the reorganization of the personal routine, access to positive sources of joy and renewing good humor to the search for support and professional help, available on websites and online service channels, including free of charge.

The Ministry of Health created a communication and support channel, through a cell phone application, to offer help to women victims of domestic, family, sexual or moral physical or psychological violence. Since 2006, recognizing the existence of such violence in the health sector, it has implemented the Violence and Accident Surveillance System through Ordinance MoH/Minister's Office 1,356. In 2011, it spread the notification of domestic, sexual and other violence to all health services. It was provided an access channel to workers, through psychological teleconsultation, to offer support and prevent future mental health problems.

Thus, welcoming professionals who suffer violence aims to mitigate illness and, consequently, improve personal development, productivity and share the experience with the team, including the administrative area, which also observes and experiences the violence present there ${ }^{(5)}$. By promoting actions based on humanization and ethics, it expresses the understanding of the importance and benefit of empathic listening and NVC aimed at professionals involved in assistance, especially in this pandemic moment.

NVC, also known as Compassionate Communication, proves to be an effective resource in welcoming professionals. It is a language based on a culture of peace that enables understanding conflicts, anguish, and suffering experienced through self-knowledge and self-connection. NVC proposes a peaceful search for overcoming violence through dialogue based on empathy. Empathetic listening aims to listen carefully to the other's observations, in a compassionate way, devoid of judgments or advice. As the person shares his questions, the listener seeks to help him identify his own feelings and needs. This sharing empowers and provides the opportunity to understand oneself, expands the possibilities to find answers, giving new meaning to the situation faced, in connection with you and with the other ${ }^{(4,9)}$.

Empathetic listening has been widely used in the face of the current pandemic as a strategy for emotional strengthening. Faced with the need for welcoming and support in coping with experienced violence, individuals feel considered, understood in their vulnerabilities and strengthened to identify their potential. The University Hospital of the State of Rio de Janeiro offered mental health care to nursing residents using Humanistic Nursing Theory to listen and welcome through empathic listening. The successful action generated a feeling of understanding, acceptance, comfort and comfort, relief from anxiety and loneliness, understanding of the experience and responsibility for the choices made ${ }^{(9)}$.

Channels made available to the nursing professional, offering empathetic listening, provide welcome and support to better cope with the crisis period, which can generate trauma, sometimes severe. Study on traumatic stress highlights that, clearly, empathetic listening helps professionals exposed to trauma situations at work, routinely, providing support so that they can define strategies and test new protective interventions or reduction of traumatic stress related to COVID-19(9-10).

In daily life, support among peers is positive and, given the seriousness of the situation, requires more extensive actions. Promoting welcoming spaces and listening channels is essential for team members to feel encouraged to identify their feelings and needs, listening to the demands $s^{(4,6,9)}$.

Empathetic listening is also valuable for identifying psychosocial vulnerable people. Offering welcoming and empathy strengthens professionals, even in demands indirectly related to work. Groups 
of qualified volunteers are in solidarity with the challenges of the category, promoting free online spaces for empathetic listening for nursing embracement, which contributes positively to give a new meaning to their demands, perceiving themselves as more strengthened and valued as a person and professional.

Concerning the study limitation, it is possibly related to the fact that NVC and empathic listening are not controlled descriptors, which may make it difficult to disseminate the practice or limit the search for relevant studies on the subject. Empathetic listening as an offshoot of NVC is relevant, since it can be an efficient resource for coping and mobilizing strategies to minimize stress factors at work and its repercussions, such as violence, bullying, turnover, absenteeism, in addition to promoting the culture of peace and strengthen nursing professionals in the pandemic period.

The authors declare no conflicts of interest and did not receive subsidies from a funding agency to carry out this research.

\section{FINAL CONSIDERATIONS}

Nursing constitutes the largest contingent of the health workforce and has shown capacity as a driving force in coping with the pandemic. This health crisis has highlighted the weaknesses of the health system, the inattention of managers and stakeholders in public policy decisions and propositions, which have long devalued health in favor of political and economic interests, severely impacting the most valuable asset of human beings, life. It is a moment of reflection to meet fundamental needs and to envisage adjustments in favor of a more efficient health system capable of offering adequate working conditions and resources, dignified remuneration, with innovative care models. The culture of peace in organizations presupposes attention to professionals in the different dimensions. As a welcoming strategy for strengthening nursing professionals, empathetic listening is a powerful resource, especially during coping with COVID-19.

\section{REFERENCES}

1. Ministério da Saúde (BR). Boletim COE COVID-19. Centro de operações de emergência em saúde pública. Semana Epidemiológica 17 (19-25/04). [Internet]. 2020[cited 2020 Apr 20]. Available from: https://portalarquivos.saude.gov.br/images/pdf/2020/April/19/BE12-Boletim-do-COE.pdf-

2. Cassiani SH, Lira JC. Perspectivas da enfermagem e a campanha Nursing Now. Rev Bras Enferm. 2018;71(5):2351-2. doi: 10.1590/0034-7167.2018710501

3. Conselho Federal de Enfermagem (COFEN). Observatório da enfermagem [Internet]. 2020[cited 2020 Sep 25] Available from: http:// observatoriodaenfermagem.cofen.gov.br

4. Azgin B. A Review on "Non-Violent Communication: A language of life" by Marshall B. Rosenberg. J Hist Cult Art Res[Internet]. 2018 [cited 2020 Sep 25];7(2):759-62. doi: 10.7596/taksad.v7i2.1550

5. Baptista PCP, Silva FJ, Santos Jr JL, Felli VEA. Violência no trabalho: guia de prevenção para os profissionais de enfermagem [Internet]. São Paulo: Coren-SP; 2017 [cited 2020 May 1]. Available from: https://portal.coren-sp.gov.br/wp-content/uploads/2018/01/PDF-site-2.pdf

6. Bordignon M, Monteiro MI. Violence in the workplace in nursing: consequences overview. Rev Bras Enferm . 2016;69(5):939-42. doi: 10.1590/0034-7167-2015-0133

7. Bastos RAl, Quintana AM, Carnavale F. Angústias psicológicas vivenciadas por enfermeiros no trabalho com pacientes em processo de morte: estudo clínico-qualitativo. Trends Psychol. 2018;26(2):795-805. doi: 10.9788/tp2018.2-10pt

8. Daly J, Jackson D, Anders R, Davidson PM. Who speaks for nursing? COVID-19 highlighting in leadership. J Clin Nurs. 2020. doi: 10.1111 / jocn.15305

9. Horesh D, Brown AD. Traumatic stress in the age of COVID-19: A call to critical aps and adapt to new realities. Psychol Trauma: Theor Res Pract Policy. 2020;12(4):331-35. doi: 10.1037/tra0000592

10. Silva AV, Santos I, Kestenberg CCF, Caldas CP, Berardinelli LMM, Silva LPS, et al. Plantão de escuta: uma aplicação da teoria humanística no processo clínico de enfermagem. Rev Enferm UERJ. 2018;26:e33586. doi:10.12957/reuerj.2018.33586 